\title{
Evaluation of sesame (Sesamum indicum L.) Varietiesfor Seed and Oil Yieldsat OmoKuraz, Southern Ethiopia
}

\author{
EnaneyTigabu Amare Girma A Q Khan \\ Arba Minch University, College of Agricultural Sciences, Plant Science Department
}

\begin{abstract}
Sesame productivity and quality can be affected to agreat extent by the nature of variety considerd for production in specific environment. Hence, field experiment was conducted at OmoKuraz -1 sugar development project of South Omo, Southern Ethiopia, during2018/19 under irrigated condition to evaluate sesame varieties for agronomic performance and oil yield. The treatment consisted of ten varieties of sesame namely: E, Tate, Kelafo74, Mehando-80, T-85, Adi, Abasena, S, Argene and Serkamo and arranged in Randomized Complete Block Design with three replications. Data were collected on phenological, growth, yield, yield components, oil content and oil yield. The data were subjected to analysis of variance using SAS software version 9.0. Varieties differed significantly for all studied characters. Accordingly, the highest seed yield $(1468.68 \mathrm{Kg} / \mathrm{ha})$, oil content $(49.18 \%)$ and oil yield $(722.29 \mathrm{~kg} / \mathrm{ha})$ were obtained from variety Tate followed by values obtained from Mehando-variety with insignificant variation. On the other hand, Abasena and $\mathrm{S}$ varieties produced the lowest seed yield. Therefore, it is possible to concludethat considering either Tate or Mehando- 80 variety for cultivation in similar areas of this study site could enable producers to harvest better seed and oil yields from sesame.
\end{abstract}

Keywords: Oil content, phenological parameter,Werer

DOI: $10.7176 / \mathrm{JBAH} / 10-8-03$

Publication date: April $30^{\text {th }} 2020$

\section{INTRODUCTION}

Sesame (Sesamum indicum L.) belonging to family Pedaliaceae is one of the oldest cultivated oil-rich plants in the world (Yasin and Genene, 2017) which is widely known for its excellent nutritional, medicinal, cosmetic and cooking qualities of its oil (Duhoonet al. 2000). It contains high amount of oil hence sesame is known as the king of oil seeds (Sharma et al., 2014). Ethiopia is among the major sesame producing countries in the world.

Despite, its superior national economic importance and great potential in improving farmers'income, the crop is almost exclusively produced by smallholders using limited number of variey with productivity below the national average yield (4.75 qt/ha) in the lowland areas of South Omo zone (Tadese and Misgana, 2017). The poor productivity might be associated genetic potential of varieties and nature of growing environment (Zenebe, 2010). Improved varieties were not tested for seed and oil yields in the study area. On the other hand, Omo kuraz sugar industry is trying to produce sesame on large scale as a secondary crop using varieties which were tested some where else but not in the study area. Therefore, this study was intended to evaluate improved varieties of sesame for agronomic traits and oil yield in the study area.

\section{MATERIALS AND METHODS}

Description of the Study Area

The study was conducted at Omo Kuraz sugar project during cropping season of 2018 under irrigated conditions. The area is located between latitudes and altitudes ranging from $5^{\circ} 8^{\prime} 18^{\prime \prime}$ to $6^{\circ} 16^{\prime} 59^{\prime \prime}$ and $35^{\circ} 43^{\prime} 37^{\prime \prime}$ to $36^{\circ} 13^{\prime}$ 54 ", respectively, in Southern part of Ethiopia about $918 \mathrm{kms}$ of Addis Ababa with elevation ranging from 370 500 meters above sea level (Tadesse and Ambachew, 2009). The mean minimum and maximum air temperatures are $23.5^{\circ} \mathrm{C}$ and $35.7^{\circ} \mathrm{C}$, respectively. Selected properties of soil of the study site are indicated in Table 1. 
Table 1. Selected physico-chemical property of soil $(0-20 \mathrm{~cm})$.

\begin{tabular}{llll}
\hline & \multicolumn{3}{c}{ Physical properties } \\
\hline Sand $(\%)$ & Silt $(\%)$ & Clay $(\%)$ & Textural class \\
\hline 12 & 10 & 78 & Clay \\
\hline & \multicolumn{3}{c}{ Chemical properties } \\
\hline pH $(1: 2.5)$ & Rating & References \\
Ec $(\mathrm{ds} / \mathrm{m})(1: 2.5)$ & 8.56 & strongly alkaline & Murphy (1968) \\
OC $(\%)$ & 0.203 & Salt free & ATA and MOA (2014) \\
Total Nitrogen (\%) & 1.69 & Medium & Tekalign (1991) \\
Available P $(\mathrm{ppm})$ & 0.05 & Low & Murphy (1968) \\
$\mathrm{Na}^{+}$ & 6.61 & Medium & Olsen et al., (1954) \\
$\mathrm{K}+$ & 1.05 & Very low & Jones (2003) \\
$\mathrm{Ca} 2+$ & 1.84 & Very low & Jones (2003) \\
$\mathrm{Mg} 2+$ & 36.8 & Very low & Jones (2003) \\
$\mathrm{CEC}\left(\mathrm{Cmol}_{\mathrm{c}} \mathrm{kg}^{-1}\right)$ & 14.8 & Very low & Jones (2003) \\
\hline
\end{tabular}

Where, $\mathrm{OC}=$ Organic carbon, $\mathrm{ppm}=$ Parts per million, $\mathrm{Ec}=$ Electrical conductivity, $\mathrm{ds} / \mathrm{m}=$ desiemens $/ \mathrm{meter}, \mathrm{Na}=$ sodium, $\mathrm{K}=$ potassium, $\mathrm{Ca}=$ calcium, $\mathrm{Mg}=$ magnesium, $\mathrm{CEC}=$ cation exchange capacity.

\section{Treatments and experimental design}

The treatments consisted of ten varieties of sesame namely: E, Tate, kefalo-74, Mehando-80, T-85, Adi, Abasena, $\mathrm{S}$, Argene and Serkamo. The seeds of the tested varieties were collected from Werer Agricultural Research Center. Th experiment was conducted in randomized complete block design (RCBD) with three replications. The varieties

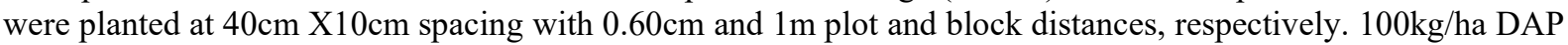
and $50 \mathrm{~kg} / \mathrm{ha}$ Urea were applied at the time of sowing and flowering initiation, respectively.

\section{Data collection}

Data were recorded on days to $50 \%$ seedling emergence, days to $50 \%$ flowering, days to $90 \%$ maturity, plant height to first branch $(\mathrm{cm})$, plant height to first capsul $(\mathrm{cm})$, internode length $(\mathrm{cm})$, drymatter $(\mathrm{kg} / \mathrm{ha})$, number of capsules per plant, number of seeds per capsule, thousand seed weight (g), seed yield $(\mathrm{kg} / \mathrm{ha})$, harvest index and oil content (\%). Oil content of seeds: - was determined following the NMR (nuclear magnetic resonance) method. Oil yield $(\mathrm{kg} / \mathrm{ha})$ was determined using the formula: Oil yield $(\mathrm{kg} / \mathrm{ha})=$ seed yield $*$ oil content of seed $/ 100)$.

\section{Data analysis}

All collected data were subjected to the analysis of variance (ANOVA) using statistical procedure described by Gomez and Gomez (1984) with the help of SAS software version 9.0 (SAS, 2004). Means were compared using least significance difference (LSD) at $5 \%$ level of significance. Correlation analysis was done to determine the magnitude and direction of relationship between parameters.

\section{Results and Discussion}

\section{Phenological parameters}

Analysis of variance showed significant variation in all phenological parameters which were measured under this experiment (Table 2). Significantly longer duration to $50 \%$ seedling emergence (9.33) was observed in Tate variety which was at statistical parity with the values obtained from varieties T-85 and Argene. Contrarily, the remaining varieties gave significantly shorter duration to $50 \%$ seedling emergence with no statistical variation.

Tate variety showed the longest durationto $50 \%$ flowering (40.33) which was statistically similar with values recorded due to Kelafo -74, Mehando-80, T- 85 and Argene varieties (Table 2). Tate also gave significantly the longest days to maturity (86.33days) followed by T-85, S and Argene. The remaining varieties showed shorter days in maturity. The significant variation in days to $90 \%$ maturity might be associated with variation in days to $50 \%$ flowering which could be supported by strong positive and very highly significant linear relationship of days to $90 \%$ maturity with days to $50 \%$ flowering $\left(\mathrm{r}=0.96^{* * *}\right)$ (Table 6). Enginetal. (2010) also studied significant and positive linear relationship between days to $50 \%$ flowering and days to $90 \%$ maturity implying early flowering in sesame provides early capsule development thereby early maturity and vice versa. 
Table 2. Variety differences in phenological parameters

\begin{tabular}{llll}
\hline Treatments & Days to 50\% Seedling emergence & Days to $\mathbf{5 0 \%}$ flowering & Days to 90\% maturity \\
\hline E & $5.66^{\mathrm{b}}$ & $37.00^{\mathrm{bc}}$ & $81.66^{\mathrm{cd}}$ \\
Tate & $9.33^{\mathrm{a}}$ & $40.33^{\mathrm{a}}$ & $86.33^{\mathrm{a}}$ \\
Kelafo -74 & $5.00^{\mathrm{b}}$ & $38.33^{\mathrm{abc}}$ & $82.00^{\mathrm{bcd}}$ \\
Mehando-80 & $6.00^{\mathrm{b}}$ & $38.66^{\mathrm{ab}}$ & $82.00^{\mathrm{bcd}}$ \\
T-85 & $8.66^{\mathrm{a}}$ & $39.00^{\mathrm{ab}}$ & $83.66^{\mathrm{b}}$ \\
Adi & $5.66^{\mathrm{b}}$ & $36.00^{\mathrm{c}}$ & $80.33^{\mathrm{d}}$ \\
Abasena & $5.33^{\mathrm{b}}$ & $37.00^{\mathrm{bc}}$ & $81.33^{\mathrm{d}}$ \\
Serkamo & $5.33^{\mathrm{b}}$ & $37.00^{\mathrm{bc}}$ & $81.66^{\mathrm{cd}}$ \\
S & $6.33^{\mathrm{b}}$ & $38.00^{\mathrm{bc}}$ & $82.66^{\mathrm{bc}}$ \\
Argene & $8.00^{\mathrm{a}}$ & $38.33^{\mathrm{abc}}$ & $82.00^{\mathrm{bcd}}$ \\
\hline Mean & 6.53 & 38 & 82.36 \\
LSD & $1.49^{\mathrm{a}}$ & 2.05 & 1.93 \\
CV $(\%)$ & 13.3 & 3.15 & 1.37 \\
\hline
\end{tabular}

With in a column means followed by the same letter(s) are not significantly different at 5\%level ofprobability.LSD = Least significant difference, $\mathrm{CV}(\%)=$ Coefficient of variation.

\section{Growth Parameters}

\section{Plant height to first branch and first capsule}

Varieties were very highly significant $(\mathrm{P}<0.001)$ differed in plant height to first branch and plant height to first capsule (Table 3). The tallest plants to first branch $(30.66 \mathrm{~cm})$ were observed in Abasena variety followed by variety Serkamo $(26.66 \mathrm{~cm})$ where as the shortest plants $(20.33 \mathrm{~cm})$ were recorded due to Tate and Kelafo-74 varieties. Abasena also produced tallest plants to first capsule $(65.66 \mathrm{~cm})$ which was not significantly different from Adi $(61.33 \mathrm{~cm})$. On the other hand, the shortestheight to first capsule $(46 \mathrm{~cm})$ was obtained from Tate followed by Mehando-80variety $(48 \mathrm{~cm})$. The observed variation in Plant height is in line with the finding of Adnan et al., (2015) who reported height differences among sesame varieties which might be attributed to genetic make up of the crop (Sana et al., 2003) and growing environment.

\section{Internode length and drymatter}

Highly significant differences $(\mathrm{P}<0.01)$ were observed in internode length of varieties (Table 3 ). The longest internode was observed in Kelafo-74 $(13 \mathrm{~cm})$ and Abasena $(13 \mathrm{~cm})$ varieties followed by variety $\mathrm{S}(12 \mathrm{~cm})($ Table 3) whereas the shortest internode $(9.66 \mathrm{~cm})$ was obtained from varieties Tate and Mehando- 80 followed by varieties $E$ and Serkamo.

Varieties were also highly significantly $(\mathrm{P}<0.01)$ differed in biomass accumulation (Table 3$)$. The highest dry matter yield ( $3418 \mathrm{~kg} / \mathrm{ha}$ ) was recorded due to varieties Adi and Argene which was in statistical similarity with drymatter produced in T-85 and Abasena varieties. Contrarily, the lowest biomass yield ( $1953 \mathrm{~kg} / \mathrm{ha})$ was observed in variety Mehando- 80 which was not statistically different from values observed in the remaining varieties (Table $3)$. The variation in drymatter accumulation among varieties might be related to variation in height of varieties which could be supported by positive and highly significant linear relationship plant height to first capsule and drymatter $\left(\mathrm{r}=0.66^{* *}\right)$ (Table 6). This finding is in line with the result of Tafese (2016) who found differences in drymatter among sesame varieties. 
Table 3. Varietal differences in growth parameters

\begin{tabular}{|l|l|l|l|l|}
\hline Treatments & PHFB $(\mathrm{cm})$ & PHFC. $(\mathrm{cm})$ & IL $(\mathrm{cm})$ & Drymatter $(\mathrm{kg} / \mathrm{ha})$ \\
\hline E & $21.33^{\text {de }}$ & $55.33^{\text {bc }}$ & $10.66^{\mathrm{bc}}$ & $2604.3^{\mathrm{bc}}$ \\
\hline Tate & $20.33^{\mathrm{e}}$ & $46.00^{\mathrm{f}}$ & $9.66^{\mathrm{c}}$ & $2604.3^{\mathrm{bc}}$ \\
\hline Kelafo -74 & $20.33^{\mathrm{e}}$ & $52.33^{\text {bcde }}$ & $13.00^{\mathrm{a}}$ & $2604.3^{\mathrm{bc}}$ \\
\hline Mehando-80 & $24.66^{\text {bc }}$ & $48.00^{\text {ef }}$ & $9.66^{\mathrm{c}}$ & $1953.0^{\mathrm{c}}$ \\
\hline T-85 & $23.00^{\text {cd }}$ & $55.00^{\mathrm{bcd}}$ & $11.33^{\mathrm{b}}$ & $2930.0^{\mathrm{ab}}$ \\
\hline Adi & $24.00^{\mathrm{c}}$ & $61.33^{\mathrm{a}}$ & $11.33^{\mathrm{b}}$ & $3418.0^{\mathrm{a}}$ \\
\hline Abasena & $30.66^{\mathrm{a}}$ & $65.66^{\mathrm{a}}$ & $13.00^{\mathrm{a}}$ & $2930.0^{\mathrm{ab}}$ \\
\hline Serkamo & $26.66^{\mathrm{b}}$ & $51.33^{\text {cde }}$ & $10.66^{\mathrm{bc}}$ & $2278.7^{\mathrm{bc}}$ \\
\hline S & $21.33^{\text {de }}$ & $50.66^{\text {de }}$ & $12.00^{\mathrm{ab}}$ & $2604.3^{\mathrm{bc}}$ \\
\hline Argene & $21.66^{\text {de }}$ & $56.33^{\mathrm{b}}$ & $11.00^{\mathrm{bc}}$ & $3418.0^{\mathrm{a}}$ \\
\hline Mean & 23.4 & 54.2 & 11.23 & 2734.5 \\
\hline LSD & 2.01 & 4.43 & 1.5 & 682.17 \\
\hline CV $(\%)$ & 5.02 & 4.76 & 7.83 & 14.54 \\
\hline
\end{tabular}

$\mathrm{PHFB}=$ plant height to first branch, $\mathrm{PHFC}=$ plant height to first capsule, $\mathrm{IL}=$ internode length

\section{Yield and Yield Related Parameters}

Very highly significant $(\mathrm{P}<0.001)$ variation was observed in number of capsules per plant, number of seeds per capsule, 1000 seed weght and seed yield among the tested varieties (Table 4). According, the maximum number of capsules per plant (54) was obtained from variety $\mathrm{S}$ which was in statistical parity with capsule number obtained from varieties E, Tate, T-85 and Argene. On the other hand, the lowest number of capsules per plant (31.66) was produced by variety Mehando- 80 which was in statistical similarity with capsule number obtained from Kefalo74 and Serkamo varieties. The variation in number of capsules per plant among varieties could be attributed to variation in the height of varieties which could be supported by positive linear relationship of capsules number with plant height (Table 6). Roy et al., (2009) also studied variation in capsule number per plant among sesame varieties. Regarding seed number per capsule, Abasena (68.00) and Mehando-80 (66.66) showed significantly higher and statistical similar values in the number of seeds per capsule wherereas significantly lower number of seeds per capsule were recorded in Adi (55.33) and Serkamo (53.66) varieties. This result agrees with the work of Morris (2009) who reported variability of number of seeds per capsules in sesame due to variety effect.

The highest thousand seeds weight $(4.27 \mathrm{~g})$ was obtained from Adi variety while the lowest and statistically similar values in 1000 seed weight were observed among E, Abasena and Argene varieties. Varieties which were in superior in number of capsules were failed to repeat their superiority in 1000 seed weight which might be associated with greater competition for sources among capsules in varieties resulting in limited translocation of assimilates to seeds leading to production of small seeds. This can be supported by negative linear relationship between capsule number and seed weight (-0.58) (Table 6). Olowe and Adeoniregun (2010) also studied significant differencesin 1000-seed weight among sesame varieties.

Among the tested sesame varieties, Tate gave the highest seed yield $(1468.68 \mathrm{~kg} / \mathrm{ha})$ over the remaining varieties which was at statistical parity with values obtained from variety Mehando-80 (1364.61kg/ha). On the other hand, Abasena gave the lowest seed yield $(740.95 \mathrm{~kg} / \mathrm{ha})$ as compared to other varieties which was at statistical parity with values obtained from Adi variety. The significant variation in seed yield among varieties might be associated with variation in days to $50 \%$ flowering, days to maturity and plant height to first capsule among varieties which could be further supported by positive and significant linear relationship of seed yield with days to $50 \%$ flowering, $\left(\mathrm{r}=0.71^{*}\right)$ and days to maturity $\left(\mathrm{r}=0.77^{* *}\right)$ (Table 6). Yasin and Genene (2017) also reported significant variation in seed yield among sesame varieties. 
Table 4. Yield and yield related traits of sesame varieties

\begin{tabular}{|c|c|c|c|c|}
\hline Treatments & $\begin{array}{l}\text { number of } \\
\text { capsules per plant }\end{array}$ & $\begin{array}{l}\text { Number of seeds } \\
\text { per capsules }\end{array}$ & $\begin{array}{l}1000 \text { seed weight } \\
\text { (g) }\end{array}$ & Seed yield (kg/ha) \\
\hline $\mathrm{E}$ & $50.66^{\mathrm{a}}$ & $62.33^{\mathrm{cd}}$ & $3.37^{\mathrm{de}}$ & $1114.74^{b}$ \\
\hline Tate & $48.00^{\mathrm{ab}}$ & $60.33^{\mathrm{d}}$ & $3.53^{\mathrm{cd}}$ & $1468.68^{a}$ \\
\hline Kelafo -74 & $36.66^{\text {cde }}$ & $65.00^{\mathrm{bc}}$ & $3.76^{\mathrm{bc}}$ & $1232.04^{b}$ \\
\hline Mehando-80 & $31.66^{\mathrm{e}}$ & $66.66^{\mathrm{ab}}$ & $3.56^{\mathrm{cd}}$ & $1364.61^{\mathrm{a}}$ \\
\hline $\mathrm{T}-85$ & $47.66^{\mathrm{ab}}$ & $64.00^{\mathrm{bc}}$ & $3.09^{\mathrm{f}}$ & $994.77^{\mathrm{c}}$ \\
\hline Adi & $39.00^{\mathrm{cd}}$ & $55.33^{\mathrm{e}}$ & $4.27^{\mathrm{a}}$ & $833.54^{\mathrm{d}}$ \\
\hline Abasena & $42.00^{\mathrm{bc}}$ & $68.00^{\mathrm{a}}$ & $3.34^{\mathrm{de}}$ & $740.95^{\mathrm{d}}$ \\
\hline Serkamo & $34.33^{\mathrm{de}}$ & $53.66^{\mathrm{e}}$ & $3.97^{b}$ & $1114.68^{b}$ \\
\hline $\mathrm{S}$ & $54.00^{\mathrm{a}}$ & $63.00^{\mathrm{cd}}$ & $3.51^{\mathrm{d}}$ & $1117.96^{\mathrm{b}}$ \\
\hline Argene & $50.66^{\mathrm{a}}$ & $64.33^{\mathrm{bc}}$ & $3.15^{\mathrm{ef}}$ & $986.38^{\mathrm{c}}$ \\
\hline Mean & 43.46 & 62.26 & 3.55 & 1096.83 \\
\hline LSD & 6.38 & 2.99 & 0.23 & 119.42 \\
\hline $\mathrm{CV}(\%)$ & 8.55 & 2.8 & 3.86 & 6.34 \\
\hline
\end{tabular}

With in a column means followed by the same letter(s) are not significantly different at $5 \%$ level of probability, LSD =Least significant difference, CV $(\%)=$ Coefficient of variation .

\section{Harvest index and oil yield}

Analysis of variance showed highly significance difference $(\mathrm{P}<0.01)$ among sesame varieties in harvest index (Table 5). Among the tested varieties, Mehando-80 gave maximum harvest index (0.40) over the rest varieties with no statistical difference with values obtained from varieties Tate and Serkamo. Contrarily, Abasena gave minimum harvest index $(0.22)$ which was not statistically different from values obtained from varieties Kelafo-74, T-85, Adi and Argene. This result agrees with the work of Dereje (2012) who reported a highly significant variation in harvest index in sesame varieties. More over, this variation may be related to variation in days to maturity and seed yield $(\mathrm{kg} / \mathrm{ha})$ among tested varieties which could be evidenced by significant linear relationship of these parameters with harvest index (Table 6).

The result of the study had also revealed significant difference $(\mathrm{P}<0.05)$ among sesame varieties in oil content (Table 5). The mean values for oil content of varieties ranged from $45.33 \%$ to $49.18 \%$ where the maximum oil content $(49.18 \%)$ was recorded in Tate which was statistically at parity values obtained from E and Serkamo varieties. On the other hand, the minimum oil content $(45.33 \%)$ was observed in variety S. Similarly, oil yield $(\mathrm{kg} / \mathrm{ha})$ was also observed to highly significantly $(\mathrm{P}<0.001)$ varied among varietiies $($ Table 5$)$. The highest oil was yield $(722.56 \mathrm{~kg} / \mathrm{ha})$ recorded in Tate variety whereas the lowest and statistically similar values of oil yields were observed in Abasena $(348.60 \mathrm{~kg} / \mathrm{ha})$ and Adi $(393.10 \mathrm{~kg} / \mathrm{ha})$ varieties. The variation in oil yield among the tested varieties might be related to their variation days to $50 \%$ flowering, days to maturity, seed yield and harvest index which can be supported by significant and strong linear relationship of oil yield with days to $50 \%$ flowering $\left(\mathrm{r}==0.71^{*}\right)$, days to maturity $\left(\mathrm{r}=0.78^{* *}\right)$, seed yield $\left(\mathrm{r}=0.99^{*}\right)$ and $(\mathrm{r}=0 . * *)$ (Table 56) implying that varieties taking longer duration to flowering and maturity could have the opportunity to get enough time for production of more photoassimilate for sink (seed). On the other hand, oil yield was negatively and very highly significantly correlated with plant height to first capsule $\left(\mathrm{r}=-0.92^{* * *}\right)$ implying that varieties having shorter height to first capsule could have better opportunity in traslocation of photoassimiliates to sink (seed) instead of their utilization of photoassimilates for vegetative growth. The current study is also in line with the report of Sana et al. (2003) who studied significant variations in oil yield among sesame varieties. 
Table 5.Harvest index, oil content and oil yield of sesame Varieties

\begin{tabular}{llll}
\hline Treatments & Harvest index & Oil content $(\%)$ & Oil yield (kg/ha) \\
\hline E & $0.31^{\mathrm{bc}}$ & $48.6^{\mathrm{ab}}$ & $541.71^{\mathrm{cd}}$ \\
Tate & $0.39^{\mathrm{ab}}$ & $49.18^{\mathrm{a}}$ & $722.56^{\mathrm{a}}$ \\
Kelafo -74 & $0.30^{\mathrm{cd}}$ & $47.16^{\mathrm{b}}$ & $580.48^{\mathrm{bc}}$ \\
Mehando-80 & $0.40^{\mathrm{a}}$ & $46.90^{\mathrm{bc}}$ & $640.14^{\mathrm{b}}$ \\
T-85 & $0.26^{\mathrm{cde}}$ & $46.98^{\mathrm{bc}}$ & $467.35^{\mathrm{ef}}$ \\
Adi & $0.23^{\mathrm{de}}$ & $47.16^{\mathrm{b}}$ & $393.10^{\mathrm{g}}$ \\
Abasena & $0.22^{\mathrm{e}}$ & $47.05^{\mathrm{bc}}$ & $348.60^{\mathrm{g}}$ \\
Serkamo & $0.34^{\mathrm{abc}}$ & $47.40^{\mathrm{ab}}$ & $528.34^{\mathrm{cde}}$ \\
S & $0.31^{\mathrm{bc}}$ & $45.33^{\mathrm{c}}$ & $507.32^{\mathrm{def}}$ \\
Argene & $0.28^{\text {cde }}$ & $47.25^{\mathrm{b}}$ & $466.22^{\mathrm{f}}$ \\
\hline Mean & 0.30 & 47.30 & 519.58 \\
LSD & 0.08 & 1.79 & 61.45 \\
CV $(\%)$ & 15.61 & 2.21 & 6.89 \\
\hline
\end{tabular}

With in a column means followed by the same letter(s) are not significantly different at $5 \%$ level of probability, $\mathrm{LSD}=$ Least significant difference, $\mathrm{CV}(\%)=$ Coefficient of variation.

Table 6. Correlation between parameters

\begin{tabular}{|c|c|c|c|c|c|c|c|c|c|c|c|c|c|}
\hline Parameters & DF & $\mathrm{DM}$ & PHFB & PHFC & IL & $\mathrm{NCP}$ & DMY & $\mathrm{NSC}$ & TSW & SY & $\mathrm{HI}$ & $\mathrm{OC}$ & $\mathrm{OY}$ \\
\hline $\mathrm{DE}$ & $0.77^{* * *}$ & $0.73^{*}$ & -0.41 & -0.35 & -0.43 & 0.52 & 0.23 & 0.06 & -0.51 & 0.29 & 0.19 & 0.31 & 0.32 \\
\hline DF & & $0.96^{* * *}$ & -0.5 & $-0.69 *$ & -0.36 & 0.21 & -0.24 & 0.32 & -0.45 & $0.71 *$ & 0.57 & 0.25 & $0.71 *$ \\
\hline $\mathrm{DM}$ & & & -0.51 & $-0.77 * *$ & -0.4 & 0.22 & -0.37 & 0.19 & -0.38 & $0.77 * *$ & $0.66^{*}$ & 0.29 & $0.78^{* *}$ \\
\hline PHFB & & & & 0.59 & 0.22 & -0.43 & -0.03 & 0.04 & 0.09 & -0.57 & -0.37 & -0.2 & -0.57 \\
\hline PHFC & & & & & 0.57 & 0.03 & $0.66^{* *}$ & 0.11 & -0.003 & $-0.94 * * *$ & $-0.93^{* * *}$ & -0.16 & $-0.92 * * *$ \\
\hline IL & & & & & & 0.08 & 0.34 & 0.29 & -0.02 & -0.57 & $-0.66^{*}$ & -0.47 & -0.6 \\
\hline $\mathrm{NCP}$ & & & & & & & 0.42 & 0.16 & -0.58 & -0.11 & -0.16 & 0.01 & -0.09 \\
\hline DMY & & & & & & & & -0.07 & -0.06 & $-0.68^{*}$ & $-0.81 * *$ & -0.02 & $-0.65^{*}$ \\
\hline $\mathrm{NSC}$ & & & & & & & & & $-0.71^{*}$ & 0.005 & -0.04 & -0.21 & -0.02 \\
\hline TSW & & & & & & & & & & 0.006 & -0.008 & -0.01 & 0.002 \\
\hline SY & & & & & & & & & & & $0.94 * * *$ & 0.34 & $0.99^{* * *}$ \\
\hline $\mathrm{HI}$ & & & & & & & & & & & & 0.27 & $0.93 * * *$ \\
\hline $\mathrm{OC}$ & & & & & & & & & & & & & 0.44 \\
\hline
\end{tabular}

Where, $\mathrm{DE}=$ Days to $50 \%$ seedling emergnce, $\mathrm{DF}=$ Days to $50 \%$ flowering, $\mathrm{DM}=$ Days to $90 \%$ maturity, $\mathrm{PHFB}$ $=$ Plant height to first branch, $\mathrm{PHFC}=$ Plant height to first capsule, $\mathrm{IL}=$ Internode length, $\mathrm{NCP}=\mathrm{Number}$ of capsule per plant, DMY $=$ Dry matter yield, NSC $=$ Number of seed per capsule, TSW $=$ thousand seed weight, $\mathrm{SY}=\mathrm{Seed}$ yield, $\mathrm{HI}=$ Harvest index, $\mathrm{OC}=$ Oil content, $\mathrm{OY}=$ Oil yield and values indicated by $*$, ** and $* * *$ denotes significant differences at $0.05,0.01$ and 0.001 levels of probability, respectively.

\section{Conclusion}

Generally, it can be concluded that producers can use either Tate or Mehando variety in order to harvest better seed and oil yields under conditions which are similar with this study area. However, further experiment needs to be under taken by considering additional varieties repeated over seasons and locations in order to produce sound recommendation.

\section{References}

Adnan AA, Dutse YB, Shaibu AS (2015). Growth, yield and phenology of sesame (Sesamum indicum L.) as affected by sowing method, variety and seed rate in Sudan savanna of Nigeria 1: 1-9.

Dereje Agizie (2012). Effect of plant density on yield and yield related traits of sesame (Sesamum indicum L.) varieties at Woyto river basin, southern Ethiopia. MSc Thesis, Haramaya University, Ethiopia.

Duhoon SS, Shrivastava N, Jharia HK (2000). Managing the diversity in sesame (Sesamum indicum L.) and Niger (Guizotia abyssinica (Lf.) Cass) for sustainable development in India. National Seminar on Biodiversity, Conservation, Management and Utilization for Sustainable Development, JNKVV Campus, Jabalpur.

Engin Y, Emre K, Seymu F, Bulent U (2010). Assessment of selection criteria in sesame by using correlation coefficients, path and factor analyses. Aust. Journal of Crop Sci.4:598-602.

Ethiopian Agricultural Transformation Agency (ATA), Ministry of Agriculture (MOA). (2014). Soil fertility status and fertilizer recommendation atlas for Tigray regional state, Addis Ababa, Ethiopia, Africa.

Gomez AK, Gomez AA (1984). Statistical Procedures for Agricultural Research, 2nd Edition. An Inter. Research Institute Book, John Willey and Sons Inc., New York, pp. 328-332.

Hazelton P, Murphy B (2007). Interpreting soil test results: 2nd Edition. CSIRO Publishing. 152p. 
Jones JB (2003). Agronomic Handbook: Management of Crops, Soils, and Their Fertility. CRC Press LLC, Boca Raton, FL, USA. 482p.

Morris JB (2009). Characterization of sesame (Sesamum indicumL.) germplasm regenerated in Georgia, USA. Genetic Resources and Crop Evolution. 56:925-936.

Murphy HF (1968). A report on fertility status and other data on some soils of Ethiopia. College of Agriculture HSU. Experimental station Bulletin No.44, Collage of Agriculture. 551p.

Olowe VI, Adeoniregun OA (2010). Seed yield, yield attributes and oil content of newly released sesame (Sesamum indicum L.) varieties. Archives of Agronomy and Soil Science 56: 201-210.

Olsen SR, Cole CV, Watanabe FS, Dean LA (1954). Estimation of available phosphorus in soils by extraction with sodium carbonate. USDA Circular. 939:1-19.

Sana M, Ali A, Malik MA, Saleem MF, Rafiq M (2003). Comparative yield potential and contents of different canola caltivars (Brassica napus L.). Pakistan Jornal of Agronomy 2:1-7.

SAS (Statistical Analysis System Institute) (2004). SAS statistical guide for personal computers, version 9.0. SAS Institute.

Sharma E, Shah IS, Khan FA (2014). Review enlightening genetic divergence in sesamum indicum based on morphological and molecular studies. International Journal Agril Crop Sci. 7:1-9.

Tadesse Mesera and MisganaMitiku (2017). Performance evaluation of sesame (sesamum indicum L.) varieties in low land area of south Omo zone, SNNPR, Ethiopia. International journal of research in agriculture and forestry. 4:38-41.

Tadesse Negi, Ambachew Damtie. (2009). Researcher Orientation Manual. Ethiopian Sugar Development Agency Research directorates, Wonji.

Tafese Altaye (2016). Genetic gain in grain yield potential and associated traits of sesame (sesamum indicum L.). Journal of biology, agriculture and health care. 6 (19):104-119.

Tekalign Tadese (1991). Soil, plant, water, fertilizer, animal manure compost analyses. Working document No.13.International Livestock Research Center for Africa, Addis Ababa.

Yasin Goa and Genene Gezahagn (2017). Participatory variety selection for enhanced promotion of improved sesame varieties a case for Konta district in southern Ethiopia. Journal of biology, Agriculture and health care. 7 (24): 1-5.

Zenebe Mekonnen and Hussien Mohammed (2010). Study on Genotype X EnvironmentInteraction of Oil Content in Sesame (Sesamum indicum L.). World Journal of Fungal and Plant Biology. 1:15-20. 